\title{
Viral Enhancement of Nasal Colonization with Haemophilus influenzae Type b in the Infant Rat
}

\author{
RICHARD H. MICHAELS ${ }^{(16)}$ AND RICHARD L. MYEROWITZ \\ Children's Hospital of Pittsburgh and the Departments of Pediatrics and Pathology, University of Pittsburgh School of \\ Medicine, Pittsburgh, Pennsylvania, USA
}

\begin{abstract}
Summary
Infant rats infected with influenza $A$ virus, Sendai (parainfluenza 1) virus or rat coronavirus were used to determine whether viral infection increases the intensity of nasal colonization with $\mathrm{Hae}$ mophilus influenzae type b (HIB). Intranasal inoculation of HIB in rats previously infected with each of these viruses resulted in nasal HIB titers at least 100-fold higher than those for controls during the first 2 wk after HIB inoculation, and as much as 10,000-fold higher during the first week. Children with cough, sneezing, or rhinorrhea could be effective disseminators of HIB if they were as heavily and persistently colonized as these virus-infected animals.
\end{abstract}

\section{Abbreviations}

cfu, colony forming units

$\mathrm{EID}_{50}, 50 \% \mathrm{egg}$ infectious dose endpoint

HIB, Haemophilus influenzae type b

TCID $_{50}, 50 \%$ tissue culture infectious dose endpoint

Attention has recently been focused on the potential for spread of meningitis and other invasive diseases due to HIB among young children in close contact $(2,14)$. HIB disease is often associated with a much increased frequency of pharyngeal HIB colonization in family members or day-care center contacts, but little is known about factors that favor communicability. Because viral respiratory infection has often occurred in patients with HIB meningitis $(4,5)$ it is conceivable that viruses could play a role in the pathogenesis and spread of HIB disease. One possibility is that viral infection of the upper respiratory tract increases the intensity of pharyngeal HIB colonization, thus facilitating dissemination of the organism to other children. An infant rat model was employed to help examine this hypothesis.

\section{MATERIALS AND METHODS}

The strains of HIB and influenza A virus, experimental animals and methods of animal inoculation, tissue homogenation and culture have all been described previously (11). Briefly, suckling Sprague-Dawley rats were inoculated intranasally with a $100 \mu \mathrm{l}$ precision syringe (Hamilton Company, Whittier, CA) attached to the plastic tubing of a pediatric infusion set (Butterfly Short 25-G, Abbott Laboratories, North Chicago, IL). Great care was employed to inoculate atraumatically by slowly ejecting $5 \mu \mathrm{l}$ of fluid, which hung as a drop on the edge of the needle, and gently touching the drop to the external nares. The fluid was usually quickly sucked into the nasal cavity during inspiration. The procedure was repeated on the same side after several minutes so that a total of $10 \mu \mathrm{l}$ of viral or bacterial suspension was inoculated.

The strain of influenza virus used was an isolate from the pharynx of a Pittsburgh child in 1976 and identified as A/Victoria $\left(\mathrm{H}_{3} \mathrm{~N}_{2}\right)$. Strains of Sendai (parainfluenzae 1) virus (VR-105) and rat coronavirus (VR-635) were obtained from the American Type Culture Collection (Rockville, MD). Nasal washings were per- formed by allowing inhalation of $20 \mu \mathrm{l}$ of normal saline and collecting the effluent from the nostrils with a capillary pipet. Washings (both undiluted and a 1:100 dilution in saline) were inoculated with a $1 \mu \mathrm{l}$ calibrated loop on antiserum agar (10). A radial streaking technique was employed that allowed enumeration of up to 300 colonies on a plate.

\section{RESULTS}

Initially, the duration and intensity of nasal HIB colonization were studied in infant rats that had been inoculated with approximately $10^{5} \operatorname{EID}_{50}(50 \%$ egg infectious dose endpoint) of influenza $A$ virus at age 3 days and with $10^{5}$ colony-forming units (cfu) of HIB 48 h later. Five animals were then sacrificed every 2-3 days until HIB could no longer be detected in homogenized nasal (snout) tissue. Using this procedure, approximately $10^{4} \mathrm{cfu}$ of $\mathrm{HIB} / \mu \mathrm{g}$ of nasal tissue could be demonstrated throughout the first week after HIB inoculation, with a decline to $10^{2.9} \mathrm{cfu} / \mu \mathrm{g}$ by the 14 th day. There was no detectable HIB by the 19th day (less than $1 \mathrm{cfu} / \mu \mathrm{g}$ ). In contrast, nasal HIB became undetectable within 24 $h$ after the same intranasal dose of HIB in animals that were not previously infected with influenza virus.

Other viruses were then studied to determine whether they would produce similar effects. Sendai (parainfluenza 1) virus and the rat coronavirus were selected because these agents are known respiratory pathogens for rodents (1). Nasal washings were substituted for nasal tissue homogenates to allow for repeated culture of large numbers of animals, and to provide quantitative data that would better reflect the portion of the nasal HIB population available for spread. In all subsequent experiments two litters, each with 15 randomly-assorted infant rats, were utilized. One litter received $10^{3}-10^{4} \mathrm{TCID}_{50}(50 \%$ tissue culture infectious dose endpoint) of virus intranasally and the other normal saline $48 \mathrm{~h}$ before the intranasal inoculation of $10^{5} \mathrm{cfu}$ of HIB.

Table 1 summarizes the results of four experiments with these two respiratory viruses. It can be seen that the effect of either Sendai virus or rat coronavirus inoculated at age 3 days was similar to that of influenza A virus, resulting in high titers of HIB $\left(10^{3}-10^{4} \mathrm{cfu} / \mu \mathrm{l}\right.$ of nasal washings) during the $2-3 \mathrm{wk}$ after intranasal HIB inoculation of virus-infected animals. HIB became undetectable during the first week after bacterial inoculation of animals that had not received virus, but there was an unexplained appearance of HIB in low titer (not exceeding $10^{2} \mathrm{cfu} / \mu \mathrm{l}$ ) between the 14th and 24th days. Similar results were obtained when Sendai virus was administered at age 8 days, and when rat coronavirus was given at age 14 days. Most animals could not be colonized with HIB when sequentially inoculated with coronavirus and HIB at the age of one month, but nasal cultures of both virus-infected and control rats revealed heavy growth of other bacteria at this time.

\section{DISCUSSION}

Halsey and associates (3) have demonstrated nasal HIB colonization for up to 24 days in infant rats repeatedly inoculated with 
Table 1. Titer of $H$. influenzae type $b$ in nasal washings from infant rats given either virus or normal saline intranasally, followed in $48 \mathrm{~h}$ by $10^{5}$ cfu of $H$. influenzae type $b$ intranasally

\begin{tabular}{|c|c|c|c|c|c|c|c|c|}
\hline \multicolumn{2}{|c|}{ Viral inoculation } & \multicolumn{7}{|c|}{ Days after inoculation of $H$. influenzae type $\mathrm{b}$} \\
\hline Sendai Virus & 3 days & $4.0^{1}$ & 4.0 & 4.1 & 3.9 & 3.0 & 0.2 & $<0.1$ \\
\hline Sendai Virus & 8 days & 4.2 & & & 4.2 & & 3.9 & 1.6 \\
\hline None (saline) & 8 days & $<0.1$ & & & $<0.1$ & $\begin{array}{l}3.9 \\
1.6\end{array}$ & 1.5 & 0.9 \\
\hline None (Saline) & 3 days & $<0.1$ & $<0.1$ & $<0.1$ & $<0.1$ & $\begin{array}{l}3.6 \\
0.6\end{array}$ & 2.0 & 0.4 \\
\hline Rat Coronavirus & 14 days & 4.1 & & 4.0 & & & & \\
\hline None (saline) & 14 days & 1.1 & & $<0.1$ & & & & \\
\hline
\end{tabular}

${ }^{1}$ Geometric mean titer, representing nasal washings from 15 rats and expressed as $\log 10 \mathrm{cfu} / \mu \mathrm{l}$.

high doses of HIB $\left(10^{5}-10^{7} \mathrm{cfu}\right.$ intranasally twice daily for 2 days). A single intranasal dose of $10^{5} \mathrm{cfu}$ produced inconsistent results in our hands; however, this same dose of HIB given $48 \mathrm{~h}$ after inoculation of a respiratory virus resulted in prolonged and intense colonization. Quantitative study demonstrated HIB titers for nasal washings from virus-infected rats that were at least 100 -fold higher than those for controls during the first 2 wk after HIB inculation, and as much as 10,000-fold higher during the first week. There was no coughing, sneezing or apparent rhinorrhea among the virus-infected rats, but children with these manifestations of upper respiratory infection might well be effective disseminators of HIB if they were as heavily and persistently colonized as the virusinfected animals that we studied.

Both intensity $(10)$ and frequency $(8,13)$ of pharyngeal HIB colonization are increased in siblings of patients with HIB meningitis or epiglottitis. We are not aware of any published virologic study of such siblings, but it is likely that respiratory viruses circulate freely among close contacts of virus-infected patients with HIB meningitis $(4,5)$. Furthermore, Sell and her coworkers (12) isolated HIB and other typable $H$. influenzae much more often from children with acute respiratory illnesses than from those who were not ill. A previous Pittsburgh study showed a higher pharyngeal HIB colonization rate in children with coryza than in those who were well, although the difference was not statistically significant (9).

The mechanism responsible for the enhancing effect of viral infection on HIB colonization in infant rats is unknown, although it might involve pathogenic mediators released from virus-infected cells or virus-induced suppression of humoral or cell-mediated immune responses. There is reason to suggest that the explanation may involve a virus-induced mucosal inflammation with consequent elaboration of growth factors for HIB (11). At any rate, the demonstrated intense and prolonged nasal HIB multiplication could well be a factor in the development of meningitis and other invasive HIB disease.

Our initial investigation was concerned with a possible viral contribution to the pathogenesis of HIB meningitis rather than with the role of viruses in the communicability of HIB. We demonstrated that the intranasal dose of HIB required to produce meningitis in infant rats was significantly reduced if the animals were pre-infected with influenza A virus (7). Subsequent studies in rats by Krasinski and Nelson have shown that the respiratory syncytial virus as well as parainfluenza 1 and 2 viruses may also potentiate the development of HIB meningitis (data presented at the 20th Interscience Conference on Antimicrobial Agents and Chemotherapy in New Orleans, 1980). Continued work in our laboratory has shown that some strains of influenza $B$ virus and the rat coronavirus may have a similar effect (6).

In summary, recent investigations have shown that various respiratory viruses may potentiate invasive HIB disease in an infant rat model. The present study has demonstrated that respiratory viruses may also greatly increase the intensity of nasal HIB colonization in rats, with possible epidemiologic as well as pathogenetic implications for human HIB infection.

\section{REFERENCES AND NOTES}

1. Baker, H. J., Lindsey, J. R., and Weisbroth, S. H.: The laboratory rat. Biology and Diseases. Vol 1. (Academic Press, New York, 1979).

2. Granoff, D. M. and Daum, R. S.: Spread of Haemophilus influenzae type b: recent epidemiologic and therapeutic considerations. J. Pediatr., 97: 854 (1980).

3. Halsey, N. A., Korock, C., Johansen, T. L., and Glode, M. P.: Intralitter transmission of Haemophilus influenzae type $\mathrm{b}$ in infant rats and rifampin eradication of nasopharyngeal colonization. J. Infect. Dis. 142: 739 (1980).

4. Kaplan, S. L., Taber, L. H., Frank, A. L., and Feigin, R. D.: Nasopharyngeal viral isolates in children with Haemophilus influenzae type $\mathrm{b}$ meningitis. J. Pediatr., 99: 591 (1981)

5. Leedom, J. M., Portnoy, B., Mathies, A. W., Jr., and Eckert, H. L.: Preliminary survey of respiratory virus infections in patients with Haemophilus influenzae meningitis. In: Hobby, G. L.: Antimicrobial Agents and Chemotherapy, 1965, p. 37. (American Society for Microbiology, Ann Arbor, 1966).

6. Michaels, R. H. and Myerowitz, R. L.: Viral potentiation of the pathogenicity of Haemophilus influenzae. In: Sell, S. H. W., and Wright, P. F.: Hemophilus Influenzae: Epidemiology, Immunology and Prevention of Disease, p. 81. (Elsevier North Holland, New York, 1982).

7. Michaels, R. H., Myerowitz, R. L., and Klaw, R.: Potentiation of experimental meningitis due to Haemophilus influenzae by influenza A virus. J. Infect. Dis., 135: 641 (1977).

8. Michaels, R. H. and Norden, C. W.: Pharyngeal colonization with Haemophilus influenzae type $\mathrm{b}$ : A longitudinal study of families with a child with meningitis or epiglottitis due to $H$. influenzae type b. J. Infect. Dis., 136: 222 (1977).

9. Michaels, R. H., Poziviak, C. S., Stonebraker, F. E., and Norden, C. W.: Factors affecting pharyngeal Haemophilus influenzae type b colonization rates in children. J. Clin. Microbiol., 4: 413 (1976).

10. Michaels, R. H., Stonebraker, F. E., and Robbins, J. B.: Use of antiserum agar for detection of Haemophilus influenzae type $\mathrm{b}$ in the pharynx. Pediatr. Res., 9: 513 (1975).

11. Myerowitz, R. L. and Michaels, R. H.: Mechanism of potentiation of experimental Haemophilus influenzae type $\mathrm{b}$ disease in infant rats by influenza $\mathrm{A}$ virus. Lab. Invest., 44: 434 (1981).

12. Sell, S. H., Turner, D. J., and Federspiel, C. F.: Natural infections with Hemophilus influenzae in children: I. Types identified. In: Sell, S. H. W. and Karzon, D. T.: Hemophilus Influenzae, p. 3. (Vanderbilt University Press, Nashville, 1973).

13. Turk, D. C.: An investigation of the family background of acute haemophilus infections in children. J. Hyg. (Camb.) 74: 315 (1975).

14. Ward, J. I., Fraser, D. W., Baraff, L. J., and Plikaytis, B. D.: Haemophilus influenzae meningitis: A national study of secondary spread in household contacts. N. Engl. J. Med., 301: 122 (1979).

15. We wish to thank Drs. John B. Robbins and Rachel Schneerson for H. influenzae type $b$ antiserum, and Drs. Carl W. Norden and Kenneth E. Schuit for reviewing the manuscript.

16. Requests for reprints should be addressed to: Dr. Richard H. Michaels, Children's Hospital of Pittsburgh, Pittsburgh, Pennsylvania 15213.

17. This work was supported by Grant R01-AI-15988 from the National Institutes of Health.

18. Received for publication June 8, 1982.

19. Accepted for publication September 21, 1982. 